\title{
Legal Antropology Approach on the Application of Village Website in Digital Economic Era in Indonesia
}

\author{
Sarip Sarip \\ Faculty of Law, University of Muhammadiyah Cirebon, Indonesia \\ E-mail : sarip@umc.ac.id \\ Diana Fitriana \\ Faculty of Law, University of Muhammadiyah Cirebon, Indonesia \\ E-mail: diana243jonna@gmail.com
}

\begin{abstract}
How to cite : Sarip, Sarip; Diana Fitriana. (2018). Legal Antropology Approach on the Application of Village Website in Digital Econmic Era in Indonesia . UNIFIKASI : Jurnal Ilmu Hukum, 5(2), 96-105. DOI : 10.25134/unifikasi.v5i2.877

Submitted : 14-03-2018 Revised : 02-08-2018 Accepted : 14-08-2018
\end{abstract}

\begin{abstract}
Legal anthropology approach is a scientific discipline which explicitly focuses on normative complexity in society and on the relationship between human behavior and its complexity and changes in both human behavior and normative complexity. The application of modern technology in villages has shown the central government's support, especially in the acceleration of village economy. On the other hand, there are not many people in the village who understand the application of the technology itself. Villages, that are vulnerable to changes, require special attention especially with regard to technology. The aim of legal anthropology in accelerating the digital economy is expected to provide a balance in the acceleration of village economy. Thus, the issue raised in this research is how the novelty and renewal of law on digital economy acceleration through the village website viewed from legal anthropology. This research used a normative legal research method which was done by describing views related to the subject matter. In terms of anthropological tendency, there is a tendency adjusted to the dynamics of the society's culture including the acceleration of digital economy for the village. Anthropology sees only law as an aspect of culture, namely an aspect used by public authority in regulating behavior and society, so that there are no deviations and irregularities of the determined social norms. Legal anthropology looks at possible differences or even conflicts in order to assess the modernization culture with the level of understanding in the village. The legal novelty and renewal in the village with regard to digital economic acceleration is considered as a channel, means, and a type of membrane that can be penetrated without disturbing or damaging the membrane.
\end{abstract}

Keywords: Anthropolog; Law; Digital; Website; Village.

\section{Pendekatan Antropologi Hukum Penerapan Website Desa di Era Ekonomi Digital di Indonesia}

\begin{abstract}
Abstrak : Pendekatan Antropologi hukum merupakan disiplin ilmiah yang paling eksplisit memusatkan perhatian pada ke-kompleksitasan normatif dalam masyarakat dan pada hubungan antara prilaku manusia dengan kekompleksitasan, perubahan-perubahan baik dalam prilaku manusia maupun dalam kekompleksitasan normatif. Penerapan teknologi modern di desa- desa telah menunjukan dukungan pemerintah pusat terutama dalam percepatan ekonomi desa. Di sisi lain masyarakat desa masih belum banyak yang mengerti akan penerapan teknologi itu sendiri. Desa yang rentan akan perubahan memerlukan perhatian yang khusus apalagi berkenaan dengan teknologi. Tujuan antropologi hukum dalam percepatan ekonomi digital diharapkan memberikan keseimbangan dalam percepatan ekonomi desa. Maka yang menjadi pertanyaan yakni bagaimana kebaruan dan pembaharuan hukum percepatan ekonomi digital melalui website desa dilihat dari sisi antropologi hukum. Penelitian sendiri menggunakan metode penelitian hukum normative dilakukan dengan cara mendeskripsikan pemikiran yang berkenaan dengan pokok bahasan. Kecenderungan antropologis, terdapat kecenderungan yang disesuaikan dengan dinamika budaya masyarakat termasuk didalamnya percepatan ekonomi digital bagi desa. Antropologi melihat hukum sebagai aspek dari kebudayaan, yaitu suatu aspek yang digunakan oleh kekuasaan masyarakat yang teratur dalam mengatur perilaku dan masyarakat, agar tidak terjadi penyimpangan dan penyimpangan yang terjadi dari norma-norma sosial yang ditentukan dapat diperbaiki.Antropologi hukum dengan melihat kemungkinan perbedaan atau bahkan pertentangan masyarakat desa dalam rangka menilai budaya modernisasi dengan tingkat pemahaman di desa.Kebaruan dan pembaharuan hukum di desa berkenaan dengan percepatan ekonomi digital dianggap sebagai saluran, sarana, sejenis selaput yang bisa ditembus tanpa mengganggu atau merusak selaput.
\end{abstract}

Kata kunci: antropologi, hukum, digital, website, desa. 


\section{INTRODUCTION}

The law can be seen from various views, but the dominant view dominating the law in Indonesia is the positivistic view ${ }^{1}$ which contradicts to law in anthropological view. Anthropological legal studies basically concern on understanding of certain communities. The view of legal anthropology is considered as a part of culture and legal culture. Legal anthropology itself is a scientific discipline which explicitly focuses on normative complexity in society and on the relationship between human behavior and its complexity as well as changes in both human behavior and normative complexity. ${ }^{2}$

In terms of the legal anthropology of urban communities in utilizing digital transactions, as analyzed by Ernst \& Young, the growth of online business sales in the country increases by $40 \%$ every year. ${ }^{3}$ There are about 93.4 million internet users and 71 million smart phone users in Indonesia. The urban community does not only use internet for browsing information and chatting, they use the internet as an e-commerce activity and it has been become a part of their lifestyle. The consumptive behavior of tens of millions of middle class people in Indonesia is the reason why e-commerce in Indonesia will continue to grow. The Minister of Communication and Information, Rudiantara, estimated the value of Indonesian e-commerce in 2016 reaches 30 billion US dollars or equivalent to Rp. 395 trillion. This figure is predicted to rise to 130 billion US dollars or equivalent to Rp. 1.714 trillion in $2020 .{ }^{4}$

In the development of legal anthropology, it has been explored even though within a broad cultural framework.

\footnotetext{
Rini Fidiyani, "Masa Depan Antropologi Hukum", Jurnal Hukum Pro Justitia, Volume 27 Nmor 1, 2009, pp. 53-66.

${ }^{2}$ F. von Benda Beckmann dalam Sumrahyadi dan Erwan Baharudin,"Antropologi Hukum dalam Implikasi Keterbukaan InformasiPublik", Lex Jurnalica, Volum 6 , Nomor 2, 2009, pp. 125-133.

3 Ernst and Young, Digital Data Opportunities, http://www.ey.com/Publication/vwLUAssets/Digital_data _opportunities .pdf accessed 20 Januari 2018.

${ }^{4}$ Tetanoe Bernada, "Upaya Perlindungan Hukum Pada Konsumen dalam Transaksi E-Commerce untuk Mendukung Pertumbuhan Ekonomi Digital di Indonesia" Jurnal Hukum dan Peradilan, Volume 6, Nomor 1, Maret 2017, pp. 1-24.
}

Anthropological scholars, such as Barton, Radcliffe-Brown, Malinowski, etc., have focused on law as a socio-cultural phenomenon. After the embryo of legal anthropology arises, the views of scholars such as Schapera, Gluckman, Hoebel, Bohannan, Pospisil, Nader, etc. have a major role in the development of legal anthropology. ${ }^{5}$ According to Ihromi, the relevance of examining the law in terms of anthropology, are: ${ }^{6}$

1. With regard to the problems faced by developing countries (including Indonesia) which are culturally pluralistic in their ideals of realizing legal unification or law modernization;

2. With regard to the possibility of the emergence of problems if the citizens of the ethnic community still have strong traditional norms; and

3. Demand compliance with certain matters, while in legal norms that have been written and applied nationally, the things that must be obeyed are precisely formulated as prohibited.

Ihromi states that the renewal of digital economic law for villages in the context of economic acceleration is the development of legal anthropology for rural development. If the government's decision or policy is considered detrimental and wrong, the decision will be challenged. On the contrary, if the policy is beneficial and appropriate, compliance will be given. $^{7}$ The classic problem that still causes different perspectives is the adaptability of rural society. As a result, legal issues and their implementation are always in contradiction so that there is no meeting point in the application. This problem is aggravated by other issues that are more complicated about the differences between cities and villages. On the other hand, the village government has a very significant role in the management and social processes in the society. ${ }^{8}$ Besides, it also leads to the

\footnotetext{
5 Soerjono Soekanto, Antropologi Hukum Proses Pengembangan Ilmu Hukum Adat. Rajawali Pers. (Jakarta: 1984), pp. 159-160.

6 T.O. Ihromi, Kajian Terhadap Hukum dengan Pendekatan Antropologi: Catatan-Catatan untuk Peningkatan Pemahaman Bekerjanya Hukum dalam Masyarakat, Gramedia, (Jakarta: 2000), pp. 3.

${ }^{7}$ Apcil Carter, Otoritas dan Demokrasi, Rajawali Press, Jakarta, 1985, pp. xvi

8 Erga Yuandra, "Kewenangan BPD (Badan Permusyawaratan Desa) dalam Menjalankan Fungsi
} 
weakness of local democracy, although it was acknowledged to have positive aspects in practice. ${ }^{9}$ Currently, re-establishing the legal anthropology approach with regard to the acceleration of digital economic growth for the village has not been widely done. Thus, based on the description above, the problems discussed in this research are formulated into the following questions: 1) What is the role of legal anthropology study in the economic acceleration of the village society? 2) What are the contributions of legal anthropology in supporting the economic acceleration of the community through the village website?

\section{METHOD}

The method used in this research is a juridical-normative research method which is done by finding information through various reading sources in the form of books, journals, and news on the internet. By analyzing the literature, it is expected to find a common thread and the benefits of legal anthropology concerning the novelty and renewal of the law in the economic acceleration field in the village, between the progress and the existing globalization challenges. This research is a descriptive qualitative research carried out by describing views relating to the subject matter. Then, the normative legal analysis is conducted through formal legal regulations which are considered to discriminate and support economic acceleration in the village. Finally, the researchers try to draw conclusions in accordance with the formulation of the problems that have been presented.

\section{RESULTS AND DISCUSSION}

\section{The Study of Legal Anthropology in the Acceleration of Rural Society}

In the development of anthropology, legal issues have been explored even though within a broad cultural framework. Anthropological scholars, such as Barton, Radcliffe-Brown, Malinowski, etc., have

Legislasi (Sebuah Telaah Sosiologis Proses Pembentukan Perdes di Desa Karamatwangi, Kecamatan Garawani, Kecamatan Kuningan)", Jurnal Unifikasi, Volueme 3 Nomor 2 Tahun 2016, pp. 64.

${ }^{9}$ Diding Rahmat dan Sarip, "Konsekuensi Dekonsentrasi dalam Pemilihan Gubernur dan Wakil Gubernur", Jurnal Unifikasi, Volume 3 Nomor 2 Tahun 2015, hlm 63. Lihat juga Multahibun dan Sarip, Ilmu Perundang-Undangan dan Teknik Pembentukan Perundang-Undangan, CV. Elsi Pro, (Cirebon: 2018), pp. 13. focused on law as a socio-cultural phenomenon. ${ }^{10}$ The relevance of examining the law in terms of anthropology, are:

1. With regard to the problems faced by developing countries (including Indonesia) which are culturally pluralistic in their ideals of realizing legal unification or law modernization; ${ }^{11}$

2. With regard to the possibility of the emergence of problems if the citizens of the ethnic community still have strong traditional norms and demand compliance with certain matters, while in legal norms that have been written and applied nationally, the things that must be obeyed are precisely formulated as prohibited.

Factually, the problems formulated into the two main points have occurred, both with regard to the emergence of horizontal conflicts in various regions, disputes between state (including local government) and the community, as well as between society groups themselves. Law, according to BendaBeckmann, is a special way to limit the autonomy of society members. Most writers agree that law is a form of social supervision. That is why law is essentially normative and it refers to what is called as objective conceptions. ${ }^{12}$

In an anthropological view, there is a tendency adjusted to the dynamics of community culture, including the acceleration of digital economy for villages. Indonesia's economic system moves into a new direction, consumers become the central point of production, the use of technology in all fields, ease of access to information that is increasingly transparent, any forms of strategic alliances and cooperation between companies (even between countries) unfold the way for the economy to get a new place.

Some people call it the New Economy. Others call it Digital Economy, Internet Economy or Economic Net (Web Economy). ${ }^{13}$

\footnotetext{
10 Sartono Sahlan, "The Other Law di Era Otonomi Daerah (Studi Antropologi Hukum)”, Jurnal Pandecta, Volume 5 Nomor 2 Tahun 2010, pp. 150.

11 Yang dimaksudkan unifikasi hukum dalam tulisan ini adalah bembentukan hukum menjadi suatu hukum formil di Indonesia yang disatukan dalam bentuk peraturan perundang-undangan dalam materi hukum yang sama.

${ }^{12}$ Sartono Sahlan, "The Other Law..., Op.Cit, pp. 156.

13 C.T. Adhikara, Siapa Konsumen Kita?: Analisis Perubahan Konsumen di Era Ekonomi Baru, Jurnal The WINNER, Volume. 6 No.2, September 2005, pp. 176183.
} 
It indicates a change that should be balanced by national law that applies nationally. The village website is one of the programs of the Ministry of Communication and Information (Menkominfo). Menkominfo even provides a one-year free website with domain berekstensi.id until 2019. ${ }^{14}$

The goal is to help entrepreneurs to promote their products through the internet. Currently, the assistance has only been available for West Java, Central Java, East Java, and Special Region of Yogyakarta. Since 2014, the government has made a breakthrough with the program of 1,000 village websites. It is a strategy to raise rural issues in public space. The aim is to influence public policy, products and potential in the village, and to improve the economy of the society. The village website program is still on progress. This program is one of the government's efforts to reduce the information gap in the village. The breakthroughs carried out by the government are directly proportional to the government's financial assistance to the village.

The Minister of Home Affairs notes that there are 74.053 villages spread throughout Indonesia in 2015. Then, the Ministry of Health records 701 new villages in 2016 so that there are 74.754 villages in 2016. The number is increasing in 2017 to 74.954 due to the addition of 200 new villages. The total population of Indonesia living in villages is around $45 \%$ (112.5 million) of the total population. The increasing number of villages in 2016 and 2017 is the result of expansion of villages. ${ }^{15}$ The expansion of villages in the past two years does not dampen the government in providing village funds.

The government's breakthrough is the development of public space in villages to support, supervise, and participate in the progress of villages. The 1,000 village website program experienced problems. The $70 \%$ of village society, who are elementary schools graduates, are less able to use the village website program maximally. ${ }^{16}$ In 2017 , the maximization of village websites has progressed which is not apart from public

\footnotetext{
${ }^{14}$ Kementrian Kominfo, http://bpmpd.ntprov.go.id/index.php/2016/08/03/websitegratis-1-tahun-dari-kementrian-kominfo/ Up Date 29 Januari 2018.

${ }^{15}$ Kemendes, Petunjuk Teknis Lomba Penulisan Artikel Dana Desa Tahun 2018, pp.1.

${ }^{16}$ Data Dinas Pendidikan Kabupaten Cirebon 2016.
}

education that began to open. Thus, in 2017, village websites begin to be filled with writings of village progress, events in the village, to village ceremonies.

The novelty and renewal of the law regarding digital economic acceleration is considered as a channel, a means, or a type of membrane that can be penetrated without disturbing or damaging the membrane. ${ }^{17}$ As an illustration, it can be described by several forms of hymen owned by a woman which is one of the hymen is elastic. ${ }^{18}$ Although, she has been having sex for several times, the membrane has remained intact. Even in a shocking event, such as rape, the hymen will not damage as evidenced in visum et revertum. Then, it is very strange when the woman is even pregnant. This kind of phenomenon should be answered with common sense as well as with the acceleration of digital economy.

The drive to accelerate digital economy has been through in-depth and thorough study. However, it has not been practiced in real conditions in the villages. For example, there is still a low level of society in the digital field. ${ }^{19}$ Therefore, law as an aspect of culture has several fundamental functions to maintain a certain position in society. This case has been explained by E.A. Hoebel, that: ${ }^{20}$

1. Formulating guidelines on how citizens should behave so that integration can be realized in society.

2. Neutralizing powers in society so that it can be used to establish orderliness.

3. Overcoming disputes so that the original state is restored.

4. Re-formulating guidelines regulating relations between citizens and groups, if there are various changes.

If we look at the description, there will be a new paradigm before taking an action to

17 Bandingkan dengan Lawrence F. Friedman, Terjemahan,The Legal System A Social Science Persepective, Russel Sage Foundation, (New York: 1998), pp. 205

${ }^{18}$ Lebih jelas tentang slaput dara (Purwanto PS dan Norman Heryandi, Aspek Medikolegal Pemeriksaan Selaput Dara Pada Korban Dugaan Perkosaan di RS. Dr. Hasan Sadikin Bandung, Perhimpunan Dokter Forensik Indonesia, Proseding Pertemuan Tahunan di Pekanbaru tanggal 15-16 Juli Tahun 2017.

${ }^{19}$ Sarip, "Kebaruan dan Pembaharuan Hukum Percepatan Ekonomi Digital Desa dalam Bingkai Negara Hukum", Jurnal Justitia, Volume 2 Nomor 1 Tahun 2018, pp. 2 ${ }^{20} \mathrm{http}: / / \mathrm{www}$.ensikloblogia.com/2016/11/pengertianantropologi-hukum-dan-ruang.html, accessed 12 Maret 2018. 
continue or stop the novelty and renewal of law in the digital era, there are generally accepted arguments. Besides, there will be a tendency to overestimate what is considered new as a must and only seen from the formal side. ${ }^{21}$ Some people even say that the drive to accelerate the digital economy has been through in-depth and thorough study. However, it has not been practiced in real conditions in the villages. It is in line with Satjipto Raharjo's view that the scope of problems that can be explored by anthropologists in the field of law is quite broad and should answer legal questions around the community, including: $:^{22}$

1. What are the types of Agencies carrying out courts and mediations roles in society?

2. What is the basis of these Agencies to carry out their role as a settlement of disputes?

3. In certain circumstances, what kind of disputes requiring a settlement through the court and which one through mediation?

4. Which functions and ecosystems work on a legal process?

5. Which procedure is used for each type of dispute under certain conditions?

6. How is the decision carried out?

7. How does the law change?

In order to answer Satjipto Rahardjo's questions, the state institutions have taken actions that are in line with legal anthropology. Based on the Court, ${ }^{23}$ it is stated that every interception should be carried out legally, specifically in law enforcement context. Therefore, the Court in its Decree adds a word "specifically" to the phrase "Electronic Information and/or Electronic Documents". It is done in order to avoid interpretation that the Decree will narrow the meaning contained in Article 5 paragraph (1) and paragraph (2) of ITE Law, and to provide legal certainty concerning the existence of Electronic Information and/or Electronic Documents as evidence that needs to be reaffirmed in the Explanation of Article 5 of ITE Law.

\footnotetext{
${ }^{21}$ Sisis formal yang dimaksudkan hanya mengacu pada peluang yang terdapat dalam peraturan perundangundangan yakni UU No.32 tahun 2004 tentang Pemerintahan Daerah yang menggantikan UU No.22 tahun 1999.

${ }^{22}$ Lihat Satjipto Rahardjo, Ilmu Hukum, Citra Aditya, (Bandung: 2010) pp. 252.

23 Putusan Mahkamah Konstitusi Nomor 20/PUUXIV/2016, Mahkamah Konstitusi berpendapat bahwa untuk mencegah terjadinya perbedaan penafsiran terhadap Pasal 5 ayat (1) dan ayat (2) UU ITE,
}

The provisions regarding searches, seizures, arrests and detentions regulated in ITE Law create problems for investigators because criminal acts in Information and Electronic Transactions are so fast and the perpetrators can easily obscure the acts or evidence. Besides, the characteristics of cyber-space that allow illegal content, such as Information and/or Electronic Documents that have content violating decency, gambling, humiliation or defamation, extortion and/or threats, dissemination of false and misleading news, results on consumer losses in Electronic Transactions, as well as acts of spreading hatred or hostility based on ethnicity, religion, race and class, and the sending of threats of violence or intimidation directed personally can be accessed, distributed, transmitted, copied, and stored for redissemination from anywhere and at any time.

In order to protect public interest from all types of disturbances as a result of misuse of Electronic Information and Transactions, it is necessary to affirm the role of the Government in preventing the dissemination of illegal content by taking action to terminate access to Electronic Information and/or Electronic Documents that have illegal content so that they cannot be accessed from the jurisdiction of Indonesia and it is necessary for the investigator to request information contained in the Electronic System Operator for the sake of criminal law enforcement in the field of Information Technology and Electronic Transactions.

The use of any information through media or Electronic Systems concerning personal data should be carried out with the consent of the person concerned. For this reason, it is necessary to guarantee personal self-protection by requiring each Electronic System Operator to delete electronic information and/or irrelevant electronic documents that are under his control at the request of the person concerned based on the court's decision.

Based on these considerations, it is necessary to establish a Law concerning Amendments to Law Number 11 of 2008 concerning Information and Electronic Transactions that reaffirm the provisions of the existence of Electronic Information and/or Electronic Documents in the Explanation of Article 5, add the provisions concerning the elimination of Electronic Information and/or Electronic documents which are not relevant in 
Article 26, amend the provisions of Article 31 paragraph (4) concerning the delegation of the formulation of interception procedures into the law, increase the role of the Government in preventing dissemination and use of Electronic Information and/or Electronic Documents that have prohibited content in Article 40, amend several provisions concerning investigations related to criminal acts in Information Technology and Electronic Transactions in Article 43, and add the explanation of Article 27 paragraph (1), paragraph (3), and paragraph (4) to be more harmonious with the material criminal law system regulated in Indonesia.

\section{The Contribution of Legal Anthropology in Supporting Economic Acceleration of the Society through Village Websites}

Anthropology sees law only as an aspect of culture, namely an aspect used by public authority in regulating behavior and society, so that there are no deviations and irregularities of the determined social norms. This Roscoe Pound's statement is brought to Indonesia at the beginning of Orde Baru by legal experts at the time with the idea that law is a social engineering tool. In civil law system applied in Indonesia, which adheres to the European law model, law is a rule of law which is actually a product of the authorities. ${ }^{24}$ In this context, law is applied by the authorities who have the authority to form law, and for the sake of law, anyone should be obedient to the rule of law.

For the village society, website can be said to be a new thing, especially to use the village website to accelerate village's economy. From a legal point of view, the existence of village website can be said to be a process of legal renewal or in other words, it is often called legal politics. ${ }^{25}$ The author deliberately uses the term legal renewal because for villagers, politic is identical with political parties. Then, the term renewal is considered appropriate to be used for the level of village society. The terms novelty and legal renewal ${ }^{26}$

\footnotetext{
${ }^{24}$ Fokky Fuad dalam, http://uai.ac.id/2011/04/13/hukumsebagai-rekayasa-sosial-kesalahan-pemahaman-ataspemikiran-roscoe-pound/ Up date 20 Januari 2018

${ }^{25}$ Bandingkan dengan istilah yang digunakan Moh. Mahfud MD. Politik Hukum di Indonesia. Raja Grafindo Persada, (Jakarta:2014).

${ }^{26}$ Kebaruan sendiri merupakan kata benda terhadap sesuatu yang sebelaumnya belum ada, kata sifatnya yakni baru sesuatu yang belum
}

are then used to see changes in villages with regard to changes in society that will be directed to the acceleration of digital economy.

To be able to ascertain the relation between legal and social change, it is necessary to analyze how law relates to society. One of the functions of law is as a social engineering tool. ${ }^{27}$ Village website program can be said to be the law as social engineering where the villagers are tried to be manipulated by the government through the village website. Here, the legal function relating to the village website program is a tool to control the society on the importance of the village website, especially the goal to accelerate digital economy.

The social change of the society carried out through the village website will influence the work of the mechanism of digital economy acceleration because there are substantial social changes in the villages with the existence of the village website. As an illustration, when there is a transition from manual transactions in villages through the village website, the society experiences a fundamental change in trade transactions. If the transaction initially involves people, now the transaction is no longer the case. Thus, to anticipate this condition, the law requires social engineering in terms of:

1. Adaptation process, including the use of technology and science that is appropriate for rural societies;

2. The process of implementing the right objectives/decision making from the policy makers so that it will not harm the village society;

3. The process of sustaining the society which is carried out through socialization on the importance of digital economy acceleration process;

4. Integration process carried out by law in terms of novelty and legal renewal in digital economic acceleration. ${ }^{28}$

The novelty and renewal of law in digital economic acceleration is the freedom to express thoughts and opinion as well as the rights to obtain information through the use and utilization of Information Technology and communication which aims to:

ada.http://kbbi.kata.web.id/?s=baru, up date 21 Januari 2017.

${ }^{27}$ Satjipto Rahardjo, Pemanfaatan Ilmu-Ilmu Sosial Bagi Pengembangan Ilmu Hukum, GentaPublishing, (Yogyakarta: 2010), pp. 123.

${ }^{28}$ Bandingkan dengan Talcott Parson dalam Satjipto Rahardjo, Pemanfaatan ..., Ibid, pp. 126. 
1. Promote public welfare;

2. Educate the nation;

3. Provide a sense of security;

4. Justice; and

5. Legal certainty for users and providers of electronic systems.

In living in the community, nation and state, the rights and freedoms on the use and utilization of Information Technology is carried out by considering the limitations set by law with the purpose of guaranteeing the recognition and respect for others' rights and freedoms and to meet the demands in accordance with moral considerations, religious values, security and public orderliness in a democratic society. ${ }^{29}$

Law Number 11 of 2008 concerning Information and Electronic Transactions (ITE Law) is the first novelty in Information Technology and Electronic Transactions as a product of legislation that is needed and has become a pioneer who determines basic regulation in the utilization of Information Technology and Electronic Transactions. ${ }^{30}$ However, a renewal is needed based on the Constitutional Court Decree Number 50/PUUVI/2008 and Number 2/PUU-VII/2009, where criminal acts of insult and defamation in Electronic Information and Electronic Transactions are not merely a general crime, but as a complaint offense. The assertion regarding the complaint offense is intended to be in harmony with the principle of legal certainty and a sense of public justice. The law as a social engineering is a tool used to lead the society to comply with legal renewal including the village society.

Based on the Constitutional Court Decree Number 5/PUU-VIII/2010, the Constitutional Court argues that activities and wiretapping authority are very sensitive because in one side it is a limitation of human rights, but on the other side it has legal interests. Therefore, regulation regarding the legality of wiretapping should be established

\footnotetext{
29 Lihat Penjelasan atas Undang-Undang Republik Indonesia Nomor 19 Tahun 2016 tentang Perubahan Atas Undang-Undang Nomor 11 Tahun 2008 tentang Informasi dan Transaksi Elektronik.

${ }^{30}$ Akan tetapi, dalam kenyataannya, perjalanan implementasi dari UU ITE mengalami persoalanpersoalan. Pertama, terhadap Undang-Undang ini telah diajukan beberapa kali uji materiildi Mahkamah Konstitusi dengan Putusan Mahkamah Konstitusi Nomor 50/PUU-VI/2008, Nomor 2/PUU-VII/2009, Nomor 5/PUU-VIII/2010, dan Nomor 20/PUU-XIV/2016.
}

and formulated in accordance with the 1945 Constitution. In addition, the Constitutional argues that wiretapping is a violation of human rights as affirmed in Article 28J paragraph (2) of the 1945 Constitution so that it is very reasonable if the state wishes to deviate from the citizens' right to privacy, the state should deviate in the form of laws and not in the form of government regulations.

The village is like a hymen that is vulnerable to the novelty and renewal of law, especially concerning the economy. The village economy cannot be separated from the history of Indonesian nation during the 3.5 century colonial era which describes the exploitation of the liberal capitalist system of the people's economy resulted in impoverishment of novelty and delays in legal renewal. An unjust socioeconomic structure arise a great determination of the proclamation of independence which is about to be transformed into a just and prosperous society based on Pancasila: the Belief in God Almighty, Just and Civilized Humanity, Indonesian Unity, and Democracy led by Wisdom in Consultation/Representatives, as well as by realizing Social Justice for All Indonesians. ${ }^{31}$ The acceleration of the digital economy of villages is faced with a dualistic between the novelty and renewal of the law.

Villages $^{32}$ in Indonesia are manipulated as an "experiment" of economic acceleration and forcing the digital world into an atmosphere of predatory global economic systems. The first manipulation in the form of economic program acceleration through the village website is failed because it is not in accordance with the capabilities of the village society, while the second manipulation by providing legal novelty and renewal based on development is considered excessive because international understanding of liberalism and neoliberalism aggressively control the Indonesian economy in a spirit of globalization.

The monetary crisis that attacked the Indonesian economy in 1997 eroded the porous modern banking sector because the capitalistic sector relied too much on foreign capital. The increasing external debts, both government and

\footnotetext{
${ }^{31}$ Pancasila sila pertama sampai sila lima.

${ }^{32}$ Desa diartikan sebagai kesatuan wilayah yang dihuni oleh sejumlah keluarga yang mempunyai sistem pemerintahan sendiri (dikepalai oleh seorang kepala desa); http://kbbi.kata.web.id/?s=desa, up date 30 Januari 2018.
} 
private debt, make the Indonesian economy more difficult because the recipe for economic restructuring (debt, revocation of subsidies and privatization) of the International Monetary Fund (IMF) does not strengthen, but weakens resilience people's economy. The Monetary Crisis also creates an atmosphere of Indonesian economic dependence on foreign capitalist forces. Social and political crises, which threaten the integrity of the nation because it exploded along with the 1997 monetary crisis, worsened because for more than 3 decades, a centralized government system has killed the creation of the region and regional societies. ${ }^{33}$

Decentralization and Regional Autonomy to increase local community participation in regional economic, social and cultural development, face obstacles from arrogant and established economic interests both at the central and in the regions. In its development, the society's economy in the regions requires capital support, which has been flowing to the center for years because of the centralistic banking system. The capital from the regions increasingly flowed to the center during the monetary crisis.

Producers and Consumers will simply carry out sales and purchase activities in markets that support each other to meet their respective needs and interests. To facilitate this production and consumption activity effectively, the economic system requires banking institutions and other financial institutions, such as capital markets, insurance institutions, guarantee institutions, pawnshops or microfinance institutions in rural areas. The movement of the economic sector from the producers of its development can be known indirectly by monitoring the data on the development of new credit facilities provided by national banks and the data on the development of production from various economic sector activities.

In this simple economic system, it will usually run on its own in normal circumstances without the need for strict regulation of the Government. The market can manage everything well and perfectly. In this economic system, the market will work automatically through strong hands that regulate it from the outside which is usually called as the invisible

\footnotetext{
${ }^{33}$ Supriyanto, "Memahami Cara Bekerja Sistem Perekonomian"Jurnal Ekonomi \& Pendidikan, Volume 6 Nomor 2, November 2009 pp. 194-195.
}

hand. Yet, in reality, the market mechanism cannot guarantee that this simple economic system model can run perfectly without distortion or loss for the wider community. In many developing countries, there is a reality of free market mechanisms that still produce many shortcomings, irregularities or fraud, or losses on the part of consumers. In a long period, there is often a tendency to group certain producers who dominate the market. In order to neutralize or reduce the losses, the role of the government or Public Institution is needed which functions to make corrections to the market system which is inefficient and unfair.

In an open economic system, we see the possibility of producers to export goods and products to other countries or, vice versa, to carry out import activities for raw materials and other materials as well as machine components or finished goods from abroad. In this economic system, banking services and financial institutions can also come from foreign sectors, such as foreign private creditors and international financial institutions.

In the era of capitalism as it is today, every human being who lives on the earth can already see, understand and feel how the impact caused by global capitalism. They will immediately be able to answer when being asked about the current face of the economy, although they cannot provide the right term for them. Everyone can immediately say that there are irregularities in the current economic order. The current face of the economy continues to lead to two very opposite poles. One pole has led the rich to become richer, while the other pole continues to drag the poor into poverty.

Therefore, one of the solutions in finding the form of the Indonesian National Economic System is a populist economic system, namely a democratic and moral-based economy with partiality in public economic sector. The protection of the public economy is a strategy to enable and empower the people of the economy who are, since the colonial era and half a century of independence, always in a helpless position. Thus, the requirements of the national economic system that should be socially justified are politically and economically independent, as well as considering cultural personality. The digital economic acceleration can be done as long as it does not damage the village's hymen because if it destroys the hymen, what is expected will be 
impossible to realize as legal engineering for novelty and renewal in villages.

\section{CONCLUSION}

From the discussion, it seems that the role and contribution of legal anthropology is quite dominant in the sense of analyzing the application of village websites in economic acceleration in the digital era. Legal anthropology looks at possible differences or even conflicts in order to assess the modernization culture with the level of understanding in the village. The legal novelty and renewal in the village with regard to digital economic acceleration is considered as a channel, means, and a type of membrane that can be penetrated without disturbing or damaging the membrane. Legal anthropology assistance makes legal unification can be well understood by rural societies, especially in rural economic growth.

\section{SUGGESTION}

The role of legal anthropology in research on policies relating to the acceleration of rural economic growth should be used to produce comprehensive policies.

\section{Books}

\section{REFERENCES}

Apcil, Carter. (1985), Otoritas dan Demokrasi, Rajawali Press, Jakarta.

Ihromi, T.O. (2000), Kajian Terhadap Hukum dengan Pendekatan Antropologi: Catatan-Catatan untuk Peningkatan Pemahaman Bekerjanya Hukum dalam Masyarakat, Gramedia, Jakarta.

Kemendes, (2018), Petunjuk Teknis Lomba Penulisan Artikel Dana Desa Tahun 2018.

Lawrence, F Friedman. (1998), Terjemahan,The Legal System A Social Science Persepective, Russel Sage Foundation, New York.

Mahfud MD.Moh. (2014), Politik Hukum di Indonesia. RajaGrafindo Persada, Jakarta.

Multahibun dan Sarip,( 2018), Ilmu PerundangUndangan dan Teknik Pembentukan Perundang-Undangan, CV. Elsi Pro, Cirebon.

Rahardjo, Satjipto. (2010), Ilmu Hukum, Citra Aditya, Bandung.
Satjipto, Rahardjo. (2010), Pemanfaatan IlmuIlmu Sosial Bagi Pengembangan Ilmu Hukum, GentaPublishing, Yogyakarta.

Soekanto, Soerjono. (1984). Antropologi Hukum Proses Pengembangan Ilmu Hukum Adat.Rajawali Pers. Jakarta

\section{Journals, Legislations, Website}

C.T. Adhikara (2005), Siapa Konsumen Kita?: Analisis Perubahan Konsumen di Era Ekonomi Baru, Jurnal The WINNER, Volume. 6 No.2, September 2005,

PS. Purwanto dan Heryandi Norman (2017). Aspek Medikolegal Pemeriksaan Selaput Dara Pada Korban Dugaan Perkosaan di RS. Dr. Hasan Sadikin Bandung, Perhimpunan Dokter Forensik Indonesia, Proseding Pertemuan Tahunan di Pekanbaru tanggal 15-16 Juli Tahun 2017.

Rahmat Diding dan Sarip (2015). "Konsekuensi Dekonsentrasi dalam Pemilihan Gubernur dan Wakil Gubernur", Jurnal Unifikasi, Volume 3 Nomor 2 Tahun 2015.

Rini Fidiyani (2009). "Masa Depan Antropologi Hukum", Jurnal Hukum Pro Justitia, Volume 27 Nmor 1, 2009.

Sahlan Sartono (2010). "The Other Law di Era Otonomi Daerah (Studi Antropologi Hukum)", Jurnal Pandecta, Volume 5 Nomor 2 Tahun 2010.

Sarip, (2018). "Kebaruan dan Pembaharuan Hukum Percepatan Ekonomi Digital Desa dalam Bingkai Negara Hukum", Jurnal Justitia, Volume 2 Nomor 1 Tahun 2018.

Sumrahyadi dan Erwan Baharudin, (2009). "Antropologi Hukum dalam Implikasi Keterbukaan Informasi Publik", Lex Jurnalica, Volum 6, Nomor 2, 2009.

Supriyanto (2009). , Memahami Cara Bekerja Sistem Perekonomian Jurnal Ekonomi \& Pendidikan, Volume 6 Nomor 2, November 2009.pp. 194-195.

Tetanoe Bernada (2017). "Upaya Perlindungan Hukum Pada Konsumen dalam Transaksi E-Commerce untuk Mendukung Pertumbuhan Ekonomi Digital di Indonesia" Jurnal Hukum dan Peradilan, Volume 6, Nomor 1, Maret 2017.

Yuhandra Erga . (2016). "Kewenangan BPD (Badan Permusyawaratan Desa) dalam Menjalankan Fungsi Legislasi (Sebuah 
Telaah Sosiologis Proses Pembentukan Perdes di Desa Karamatwangi, Kecamatan Garawani, Kecamatan Kuningan)", Jurnal Unifikasi, Volume 3 Nomor 2 Tahun 2016.

Undang-Undang Nomor 32 tahun 2004 tentang Pemerintahan Daerah yang menggantikan Undang-Undang Nomor 22 tahun 1999.

Undang-Undang Republik Indonesia Nomor 19 Tahun 2016 tentang Perubahan Atas Undang-Undang Nomor 11 Tahun 2008 tentang Informasi dan Transaksi Elektronik.

Putusan Mahkamah Konstitusi Nomor 50/PUU$\mathrm{VI} / 2008$, Nomor 2/PUU-VII/2009, Nomor 5/PUU-VIII/2010, dan Nomor 20/PUU-XIV/2016.

http://kbbi.kata.web.id/?s=baru, up date 21 Januari 2017.

Fokky Fuad dalam,

http://uai.ac.id/2011/04/13/hukumsebagai-rekayasa-sosial-kesalahanpemahaman-atas-pemikiran-roscoepound/Up date 20 Januari 2018.

http://bpmpd.ntprov.go.id/index.php/2016/08/0 3/website-gratis-1-tahun-darikementrian-kominfo/ Up Date 29 Januari 2018. 